\title{
Restriction and Modification in Bacillus subtilis: Inducibility of a DNA Methylating Activity in Nonmodifying Cells
}

\author{
URSULA GÜNTHERT,* BRIGITTE PAWLEK, JOAN STUTZ, AND THOMAS A. TRAUTNER \\ Max-Planck-Institut für molekulare Genetik, Berlin-Dahlem, Germany
}

Received for publication 16 April 1976

\begin{abstract}
The nonrestricting/nonmodifying strain Bacillus subtilis $222\left(\mathrm{r}^{-} \mathrm{m}^{-}\right)$can be induced to synthesize a DNA-modifying activity upon treatment with either mitomycin C (MC) or UV light. This is shown by the following facts. (i) Infection of MC-pretreated 222 cells with unmodified SPP1 phage yields about $3 \%$ modified phage that are resistant to restriction in B. subtilis $\mathrm{R}\left(\mathrm{r}^{+} \mathrm{m}^{+}\right)$. The induced modifying activity causes the production of a small fraction of fully modified phage in a minority class of MC-treated host cells. (ii) The MC-pretreated host cells contain a DNA cytosine methylating activity: both bacterial and phage DNAs have elevated levels of 5-methylcytosine. (iii) The MC-induced methylation of SPP1 DNA takes place at the recognition nucleotide sequences of restriction endonuclease $\mathrm{R}$ from $B$. subtilis $\mathrm{R}$. (iv) Crude extracts of MC-pretreated 222 cells have enhanced DNA methyltransferase activities, with a substrate specificity similar to that found in modification enzymes present in (constitutively) modifying strains.
\end{abstract}

Modification is a process of base- and sequence-specific DNA methylation, which leads to resistance of such modified DNA against the action of restriction enzymes recognizing the same base sequence.

In a previous communication (6), we demonstrated that modification of Bacillus subtilis and phage SPP1 DNAs against endonuclease $B s u \cdot \mathbf{R}$ restriction is correlated with enhanced levels of 5-methylcytosine (5MC) in such DNAs. We conclude that the modification is caused by methylation of two of the four cytosine (C) residues in the endoR $B$ su $R$ restriction sequence 5 '-G-G-C-C (2), which is known to occur 80 times per SPP1 genome (3). This modification-specified methylation represents in both modified SPP1 and B. subtilis DNAs a major portion of the total DNA methylation (6), in contrast to the reverse situation observed with Escherichia coli restriction/modification systems. The analyzed $B s u \cdot R$-specific methylation is a constant feature of modified SPP1 phage (SPP1 R ) DNA or bacterial DNA from cells with a restricting/modifying $\left(\mathrm{r}^{+} \mathrm{m}^{+}\right)$phenotype.

However, Arwert and Rutberg (1) discovered that phages $\phi 105$ and SPO2 grown in nonrestricting/nonmodifying $\left(\mathrm{r}^{-} \mathrm{m}^{-}\right)$B. subtilis cells that had been pretreated with mitomycin $C$ (MC) became partially resistant to $B s u \cdot R$ restriction. If this $\mathrm{MC}$-induced resistance to restriction were also due to DNA methylation, it would imply that normal cells, which are phe- notypically nonmodifying, carry a gene(s) for a modification-type methyltransferase. This implication would lead to the question of why such genetic information is only expressed after $\mathrm{MC}$ induction. In this paper we investigate the following questions: Is MC-induced resistance to restriction also caused by methylation? Is the specificity of an MC-provoked methyltransferase identical to that of the methyltransferase active in restricting and modifying type $R$ cells of $B$. subtilis?

\section{MATERIALS AND METHODS}

Bacteria and phages. (i) Nonrestricting/nonmodifying strains included: $B$. subtilis $168\left(\operatorname{trp} \mathrm{C}_{2}\right)(14), B$. subtilis 222 (arg trp $\mathrm{C}_{2}$ ) (15), B. subtilis $\mathrm{MCB}\left(\operatorname{trp} \mathrm{C}_{2}\right)$ (13); (ii) restricting/modifying strains included: $B$. subtilis 5GR (met nic ura tyr rib), B. subtilis R (15). Phages were SPP1 (9) and SPO1 (8).

Media and plates. MIIIM medium, used for the growth of bacteria, for soft agar, and for the preparation of lysates of SPO1 was a modified Spizizen (14) medium supplemented appropriately for strain requirements (4). LTT plates were as described by Spatz and Trautner (12). TY medium was as described by Rottländer and Trautner (10).

Chemicals. Chemicals used in this study were: $\left[2-{ }^{3} \mathrm{H}\right]$ adenine (specific activity, $18 \mathrm{Ci} / \mathrm{mmol}$ ), [6${ }^{3} \mathrm{H}$ ] uridine (specific activity, $10 \mathrm{Ci} / \mathrm{mmol}$ ), $S$-adenosyl-L-[methyl $\left.{ }^{3} \mathrm{H}\right]$ methionine (specific activity, 7.5 $\mathrm{Ci} / \mathrm{mmol}$ ) (all radiochemicals from the Radiochemical Centre, Amersham), MC (Calbiochem), and Aquasol (New England Nuclear Corp.).

Conditions for induction of modification. (i) MC. The following procedure was adopted to give a maximal degree of resistance to restriction. Strain 222 
was grown at $37^{\circ} \mathrm{C}$ to a density of $5 \times 10^{8}$ cells $/ \mathrm{ml}$ in TY medium. MC was added to a final concentration of $2 \mu \mathrm{g} / \mathrm{ml}$, and incubation was continued for a further $30 \mathrm{~min}$. The cells were then washed free of MC by two cycles of centrifugation and resuspended in the original volume of TY. Such cells served as the source of bacterial DNA and crude extract of methyltransferase. For one-step growth experiments, SPP1 was added to such cells at an input multiplicity of 10 . After $15 \mathrm{~min}$, the mixture was diluted 10fold, nonadsorbed phages were removed by filtration, and the infected cells were resuspended in five times the volume of the adsorption mixture of TY. Incubation continued at $37^{\circ} \mathrm{C}$. Samples were plated on nonrestricting (MCB) and restricting hosts (5GR) after various times. An analogous procedure was followed in single-burst experiments except that after removal of unadsorbed phages dilutions intended to give less than one infected center per tube were made in prewarmed test tubes. After $3 \mathrm{~h}$ of incubation at $37^{\circ} \mathrm{C}$, the contents of each tube were plated on the appropriate indicator strains. Mass lysates of SPP1 grown on cells pretreated with MC as above (called SPP1 - MC) were harvested at 4 to 6 $h$ after addition of phages to a multiplicity of infection (MOI) of 0.1 .

(ii) UV. Cells of strain 222 grown as above in TY were washed and resuspended in Spizizen (14) salt solution to a density of about $10^{8}$ cells $/ \mathrm{ml}$. Samples were removed after varying times of UV irradiation (Sterisol F1140 Lamp, Hanau). After removal of small portions from each irradiated sample to assay bacterial survival, the remainder was centrifuged, resuspended in fresh TY medium, and infected with nonmodified SPP1 phages (SPP1.0) at an input multiplicity of 1 . After $4 \mathrm{~h}$ of incubation, the lysates were clarified by centrifugation and phage titers were determined on strains MCB $\left(\mathrm{r}^{-} \mathrm{m}^{-}\right)$and 5GR $\left(\mathrm{r}^{+} \mathrm{m}^{+}\right)$. All operations with cells exposed to UV irradiation were carried out in the dark.

Radioactive labeling of DNA. In all determinations of DNA methylation in vivo, we have used radioactive base labeling instead of the commonly used methyl group labeling (6).

(i) Bacterial DNA. Strains $222\left(\mathrm{r}^{-} \mathrm{m}^{-}\right)$and 5GR $\left(\mathrm{r}^{+} \mathrm{m}^{+}\right)$were grown in $50 \mathrm{ml}$ of minimal medium (MIIIM) (4) to a density of $2 \times 10^{8}$ to $3 \times 10^{8} \mathrm{cells} / \mathrm{ml}$. Cells were then incubated with $\left[2-{ }^{3} \mathrm{H}\right]$ adenine $(1$ $\mu \mathrm{Ci} / \mathrm{ml})$ and $\left[6{ }^{3} \mathrm{H}\right]$ uridine $(2 \mu \mathrm{Ci} / \mathrm{ml})$ for one generation. They were subsequently exposed to $\mathrm{MC}$ in the presence of label (controls without addition of MC were also analyzed) under standard conditions. The DNA was extracted as described previously (6).

(ii) Phage DNA. Strain 222 cells at a cell density of $5 \times 10^{8} \mathrm{cells} / \mathrm{ml}$ in minimal medium were treated with MC under standard conditions (controls were without addition of MC). After washing the cells and resuspending them in fresh minimal medium, they were infected with SPP1 or SPO1 phages (multiplicity of infection of 0.1 ), and $10 \mu \mathrm{Ci}$ each of [2$\left.{ }^{3} \mathrm{H}\right]$ adenine and $\left[6-{ }^{3} \mathrm{H}\right]$ uridine per $\mathrm{ml}$ were added. Complete lysis occurred after 4 to $6 \mathrm{~h}$. The phage were then isolated and plated to establish the restriction ratio, and their DNAs were prepared as described previously (6).
DNA preparations for transformation, transfection, and in vitro methylation. DNAs of SPP $1 \cdot O$, SPP1 R, SPP1 MC, and SPO1 were prepared by phenol extraction of concentrated, CsCl-purified phage stocks. Bacterial DNA was isolated as described by Bron et al. (3). Transfection assays were performed as described by Bron et al. (3). Nucleotide base analysis by a coupled two-dimensional cellulose and silica gel thin-layer chromatography was performed as described by U. Günthert (Ph.D. thesis, Univ. of Tübingen, Tübingen, Federal Republic of Germany, 1975) and Günthert et al. (Proc. Natl. Acad. Sci. U.S.A., in press).

Treatment of DNA with endoR.Bsu $\mathrm{R}$ and agarose gel electrophoresis of DNA was as described by Bron et al. (3). The enzyme preparation used was a purified DEAE-cellulose fraction as described by Bron et al. (3).

Preparation of crude cell extracts. Untreated bacteria and bacteria exposed to MC under standard conditions were concentrated by centrifugation. A total of $5 \times 10^{11}$ cells were suspended in $5 \mathrm{ml}$ of TMA buffer (10 mM Tris-hydrochloride, $10 \mathrm{mM}$ $\mathrm{MgCl}_{2}, 22 \mathrm{mM} \mathrm{NH}_{4} \mathrm{Cl}, 1 \mathrm{mM}$ dithiothreitol, $\mathrm{pH}$ 7.5) and lysed in the French pressure cell press. The lysates were centrifuged at $4^{\circ} \mathrm{C}$ for $90 \mathrm{~min}$ at 100,000 $\times g$, and the supernatant was taken as the source of the methylating enzymes. All cell extracts were adjusted to a protein concentration of $10 \mathrm{mg} / \mathrm{ml}(7)$ and treated with DNase I (Worthington) $(50 \mu \mathrm{g} / \mathrm{ml})$ for $30 \mathrm{~min}$ at $37^{\circ} \mathrm{C}$.

DNA methyltransferase assay. The reaction mixture contained, in a total volume of $100 \mu \mathrm{l}: 0.6 \mu \mathrm{mol}$ of Tris-hydrochloride ( $\mathrm{pH} 7.5$ ), $0.7 \mu \mathrm{mol}$ of $\mathrm{NH}_{4} \mathrm{Cl}$, $0.1 \mu \mathrm{mol}$ of $\mathrm{MgCl}_{2}, 0.05 \mu \mathrm{mol}$ of dithiothreitol, 1.3 $\mu \mathrm{mol}$ of EDTA, $10 \mu \mathrm{g}$ of RNase (DNase free), $5 \mu \mathrm{g}$ of DNA, $100 \mu \mathrm{g}$ of protein extract, and $0.67 \mathrm{nmol}$ of $S$. adenosyl-L-[methyl- $\left.{ }^{3} \mathrm{H}\right]$ methionine $(5 \mu \mathrm{Ci})$. The mixture was incubated in Eppendorf microtest tubes $(1.5 \mathrm{ml})$ for $90 \mathrm{~min}$ at $37^{\circ} \mathrm{C}$. The reaction was stopped by addition of $100 \mu$ l of $10 \%$ sodium dodecyl sulfate, and the mixture was heated for $10 \mathrm{~min}$ at $60^{\circ} \mathrm{C}$. One hundred microliters of sonicated salmon sperm DNA $(5 \mathrm{mg} / \mathrm{ml}$ ) was added as carrier DNA, and the mixture was then deproteinized with $360 \mu$ l of chloroform-isoamyl alcohol (24:1) and $60 \mu \mathrm{l}$ of $5 \mathrm{M}$ sodium perchlorate. The aqueous phase was collected and the nucleic acids were precipitated by the addition of $500 \mu$ l of $5 \mathrm{~N}$ perchloric acid (PCA). After $10 \mathrm{~min}$ at $0^{\circ} \mathrm{C}$, the precipitate was centrifuged and washed once with $500 \mu$ l of 0.5 N PCA. Residual RNA was hydrolyzed with $500 \mu$ l of $1 \mathrm{~N} \mathrm{NaOH}$ for 20 min at $60^{\circ} \mathrm{C}$. The DNA was again precipitated by addition of $50 \mu \mathrm{l}$ of $10 \mathrm{~N} \mathrm{HCl}$ and $1,000 \mu \mathrm{l}$ of absolute ethanol and placing the reaction mixture at $-20^{\circ} \mathrm{C}$ for 1 to 2 h. After centrifugation, the pelleted DNA was washed once with $70 \%$ ethanol and then hydrolyzed in $500 \mu \mathrm{l}$ of $0.5 \mathrm{~N} \mathrm{PCA}$ for $20 \mathrm{~min}$ at $90^{\circ} \mathrm{C}$. The hydrolysate was counted in Aquasol scintillation fluid.

\section{RESULTS}

Induction of restriction resistance. (i) MC. Arwert and Rutberg (1) demonstrated that MC 
treatment of nonmodifying $B$. subtilis cells before infection with phage $\phi 105$ and SPO2 significantly increased the restriction ratio (ratio of phage titers on the restricting host to that on the nonrestricting host) of the resulting lysates. This effect of MC is also observed with the virulent phage SPP1: Fig. 1 shows one-step growth curves and development of restriction resistance of SPP1 after infection of untreated and MC-pretreated cells. After one cycle of growth, the restriction ratio was $2 \times 10^{-5}$ in lysates from untreated cells and $2.5 \times 10^{-3}$ in lysates from MC-pretreated cells. Restriction enhancement is also observed in mass lysates

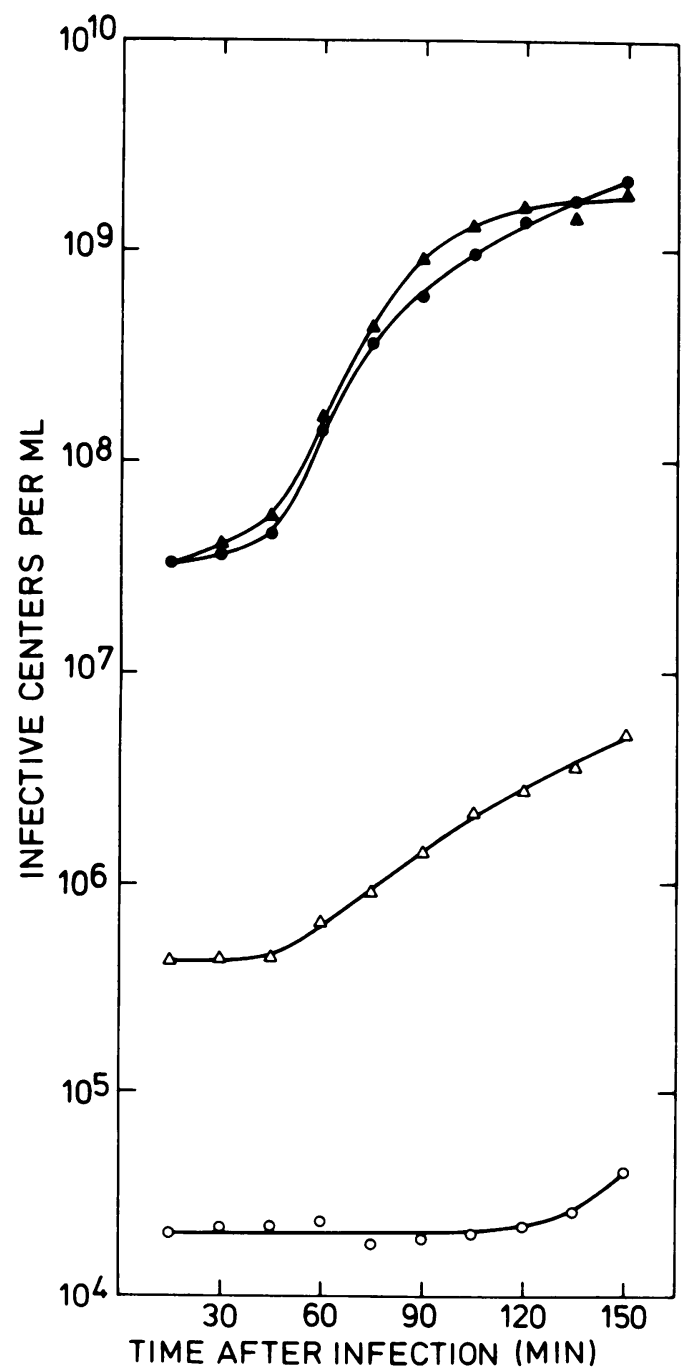

Fig. 1. One-step growth curves of SPP1 on untreated and MC-pretreated 222 cells. Infective centers from untreated cells plated on MCB (O) and $5 G R$ (O), and from MC-pretreated cells plated on $M C B$ $\left(r^{-} m^{-}\right)\left(\Delta\right.$ and on $5 G R\left(r^{+} m^{+}\right)(\Delta)$.
(Table 1). Under such conditions, the restriction ratio has consistently been higher than that observed in one-step experiments.

The experiments in Fig. 1 and Table 1 were performed using MC at a concentration of $2 \mu \mathrm{g} /$ $\mathrm{ml}$. MC at concentrations of less than $1 \mu \mathrm{g} / \mathrm{ml}$ is not as effective, whereas concentrations of greater than $4 \mu \mathrm{g} / \mathrm{ml}$ lead to very slow growth of the cells and low phage yields even after removal of MC. The restriction ratio was the same using cells treated for various times between 15 and $90 \mathrm{~min}$, although phage yields were reduced 10-fold with exposure times of more than $60 \mathrm{~min}$. In contrast to results reported by Arwert and Rutberg (1) for SPO2 and $\phi 105$, we do not find as drastic an effect of the time elapsed between removal of $\mathrm{MC}$ and phage infection on the phage yield (Fig. 2). At $90 \mathrm{~min}$ after removal of $M C$, phage infection and growth is no different from the zero time infection. The difference between the restriction ratios of the two pairs of curves shown in Fig. 2 is within the range of normal statistical variation.

The MC-mediated enhancement to restriction resistance might result from the production of SPP1 phages with type $R$ modification. The extent of modification in such phages could be at any level between partial and complete modification (see subsequent section). Such modified phages could arise from MC-pretreated cells in any situation between these extremes: (i) all modified phages are produced in a few bursts, (ii) every infected cell yields modified phages with the probability of the restriction ratio observed in MC lysates. A singleburst experiment was performed to analyze this situation. Cells pretreated with MC and infected with SPP1 were plated on strains 5GR and MCB to obtain the restriction ratio, and diluted and distributed into test tubes so that each tube received on the average 0.6 infective centers when plated with the nonrestricting host (set A in Table 2). To compensate for the restriction of phages on the restricting host, each tube of the sets to be plated with this indicator (set $B$ in Table 2) received 50 or 100 times as many infective centers. If modified

TABLE 1. Effects of $M C$ on restriction of SPP1

\begin{tabular}{|c|c|c|c|}
\hline \multirow[b]{2}{*}{ Phage } & \multicolumn{2}{|c|}{ Titer on } & \multirow{2}{*}{$\begin{array}{l}\text { Restriction } \\
\text { ratio }^{\alpha}\end{array}$} \\
\hline & $\begin{array}{c}\mathrm{MCB} \\
\left(\mathbf{r}^{-} \mathbf{m}^{-}\right)\end{array}$ & $\begin{array}{c}\text { 5GR } \\
\left(\mathbf{r}^{+} \mathbf{m}^{+}\right)\end{array}$ & \\
\hline $\begin{array}{l}\text { SPP1·O } \\
\text { SPP1 } 1 \text { MC }\end{array}$ & $\begin{array}{l}2.0 \cdot 10^{10} \\
2.2 \cdot 10^{9}\end{array}$ & $\begin{array}{l}4.5 \cdot 10^{5} \\
5.3 \cdot 10^{7}\end{array}$ & $\begin{array}{l}2.3 \cdot 10^{-5} \\
2.4 \cdot 10^{-2}\end{array}$ \\
\hline
\end{tabular}

a Stocks of SPP1 $\cdot \mathrm{O}$ and SPP1 $\cdot \mathrm{MC}$ were plated on MCB and 5GR to establish their restriction ratio. 


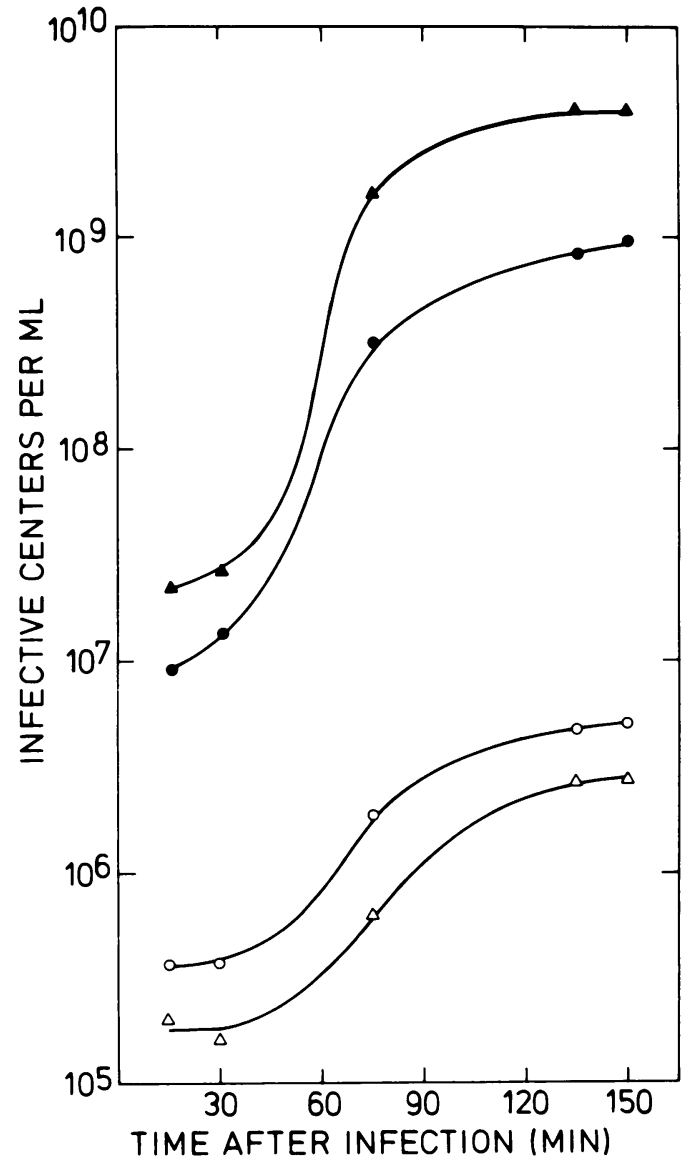

Fig. 2. One-step growth curves of SPP1 established at times 0 min $(\Delta)$ and $(\Delta)$ and 90 min after removal of $M C$ (O) and (O). Platings were on $M C B$ $\left(r^{-} m^{-}\right)$(filled symbols) and on 5GR $\left(r^{+} m^{+}\right)$(open symbols).

phage were produced exclusively according to situation (ii) above, one would expect an average number of modified plaques in tubes of sets $B$ that would be given by the expected number of nonmodified phages per tube of set B multiplied by the restriction ratio. This value is 20 for set $B_{1}$ and 40 for set $B_{2}$. Taking into account a sixfold lower plating efficiency of modified phage on strain 5 GR (Table 2), this would give average numbers of modified phage per tube of 3 and 6 for sets $B_{1}$ and $B_{2}$, respectively, which are not compatible with the observed numbers of tubes without phage (Table 2). These observed numbers are, however, in agreement with the prediction made on the basis of situation (i) above, according to which a few modified phage-producing cells should follow a Poisson distribution in tubes of set $B$. The calculated zero class values of such a distribution for $\mathrm{B}_{1}$ are $\mathrm{p}(0)=\mathrm{e}^{-28\left(1.5 \times 10^{-2}\right)}=\mathrm{e}^{-0.42}=0.66$ and for $B_{2}, p(0)=e^{-55\left(1.5 \times 10^{-2}\right)}=e^{-0.82}=0.44$, in good agreement with the observed values of $74 \%\left(\mathrm{~B}_{1}\right)$ and $61 \%\left(\mathrm{~B}_{2}\right)$. Whether bursts with modified phages also contain nonmodified particles cannot be analyzed with this type of experiment.

(ii) UV irradiation. In Fig. 3, we have plotted the survival of strain 222 cells as a function

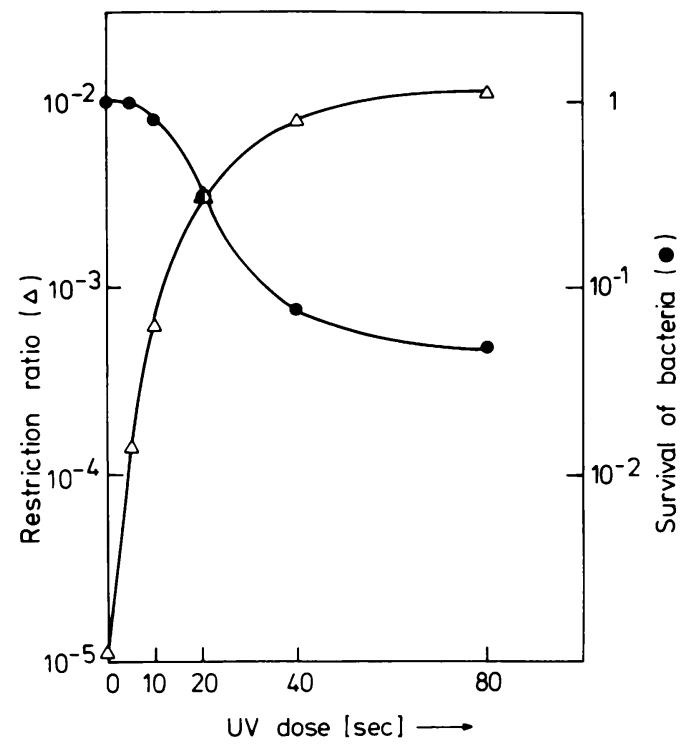

Fig. 3. Influence of UV irradiation of 222 cells on the restriction ratio of SPP1 propagated on such bacteria.

TABLE 2. Single-burst experiment ${ }^{a}$

\begin{tabular}{ccccccc}
\hline Set & Plating bacteria & $\begin{array}{c}\text { Relative } \\
\text { concn of in- } \\
\text { fected cells/ } \\
\text { tube }\end{array}$ & $\begin{array}{c}\text { No. (\%) of tubes } \\
\text { scored }\end{array}$ & $\begin{array}{c}\text { No. (\%) of tubes } \\
\text { without phage }\end{array}$ & $\begin{array}{c}\text { Avg no. } \\
\text { of bursts/ } \\
\text { tube }\end{array}$ & $\begin{array}{c}\text { Avg burst } \\
\text { size observed }\end{array}$ \\
\hline $\mathrm{A}$ & $\mathrm{MCB}\left(\mathrm{r}^{-} \mathrm{m}^{-}\right)$ & 1 & $104(100)$ & $59(57)$ & 0.55 & 42 \\
$\mathrm{~B}_{1}$ & & 50 & $72(100)$ & $53(74)$ & 0.31 & 11 \\
$\mathrm{~B}_{2}$ & $5 \mathrm{GR}\left(\mathrm{r}^{+} \mathrm{m}^{+}\right)$ & 100 & $72(100)$ & $44(61)$ & 0.51 & 3 \\
\hline
\end{tabular}

${ }^{a}$ Infective centers plated before lysis gave titers of $2.50 \times 10^{7}$ and $3.81 \times 10^{5}$ on strains MCB and 5GR, respectively; this corresponds to a restriction ratio of $1.5 \times 10^{-2}$. 
of UV dose and the restriction ratio of SPP1 mass lysates produced on cells that had been irradiated for the times indicated. It is obvious that increasing UV doses induce increasing restriction resistance in SPP1.O phages propagated on cells exposed to UV irradiation. The maximum level of UV-induced restriction resistance is similar to that observed after MC induction.

Methylation levels in bacterial and phage DNAs isolated after MC treatment of cells. To establish whether MC-enhanced resistance to restriction was due to methylation-linked modification we have studied the effects of preincubation of cells with MC on the content of methylated bases in bacterial DNAs (Table 3) and phage DNAs (Table 4). Molecular weights and guanine plus cytosine contents of DNAs analyzed are given in reference 6 .

In strain $222\left(\mathrm{r}^{-} \mathrm{m}^{-}\right)$, there is no difference in the $N$-6-methyladenine (6MA) content in treated and nontreated cells, but a remarkable increase in the 5MC content occurs after exposure to MC. In contrast to untreated cells in which only $0.13 \%$ of $\mathrm{C}$ is methylated, the $5 \mathrm{MC}$ content in pretreated cells is increased more than 10 -fold to $1.42 \%$. This is very close to the level of methylation observed in DNA from cells of the normally modified strains (6). We conclude that MC treatment of $\mathbf{r}^{-} \mathrm{m}^{-}$cells induces a methyltransferase that methylates $\mathrm{C}$ to 5MC. We have also analyzed the effect of MC pretreatment on the DNA of the modifying strain 5GR. Here we observe a small increase in $5 \mathrm{MC}$ content. In addition, $0.2 \%$ of the ade- nines are present as 6MA.

The effects of MC treatment of strain 222 on phage DNAs (Table 4) indicate, for SPP1, no change in 6MA content. There is, however, a small and significant difference of $0.04 \% 5 \mathrm{MC} /$ $\mathrm{C}$ between phages obtained from treated and untreated cells $(0.07$ and $0.11 \% 5 \mathrm{MC} / \mathrm{C}$, respectively). This may reflect a slight enhancement of MC in all SPP1.MC phages or complete methylation of a small subpopulation in such stocks.

MC treatment of host cells does not greatly alter the cytosine methylation of SPO1 DNA (Table 4). Thus this DNA, which is a poor substrate for the modification-specific methyltransferase in $\mathrm{r}^{+} \mathrm{m}^{+}$strains (6), is also a very poor substrate for any induced methyltransferase.

Distribution of 5MC in SPP1 - MC DNA. The biological tests described before indicated that only a small proportion of SPP1 $\cdot$ MC could be modified. In agreement, chromatographic analyses of SPP1 - MC DNA indicate an increase in the cytosine methylation of $0.04 \%$ upon infection of MC-treated host cells. If a molecule of methylated phage DNA from an SPP1.MC stock were as fully methylated as DNA from $\mathrm{SPP} 1 \cdot \mathrm{R}(5 \mathrm{MC} / \mathrm{C}=1.26 \%[6])$, this would indicate that $3 \%$ of the DNA molecules were totally modified and the rest not at all. Alternatively, the additional $0.04 \%$ methylation could be distributed continuously among the population of DNA molecules to create phages with intermediate levels of modification. To distinguish between these possibilities, we have subjected

TABLE 3. Effects of MC on in vivo methylation of bacterial DNA ${ }^{a}$

\begin{tabular}{lcrrrrrrrr}
\hline $\begin{array}{c}\text { Source of } \\
\text { DNA }\end{array}$ & $\begin{array}{c}\text { Mito- } \\
\text { mycin }\end{array}$ & A (cpm) & $\begin{array}{c}\text { 6MA } \\
\text { (cpm) }\end{array}$ & $\begin{array}{c}\text { \% 6MA/ } \\
\text { A }\end{array}$ & $\begin{array}{c}\text { Avg no. of } \\
\text { 6MA per } \\
\text { genome }\end{array}$ & C (cpm) & $\begin{array}{r}\text { 5MC } \\
\text { (cpm) }\end{array}$ & $\begin{array}{c}\text { \% 5MC/ } \\
\text { C }\end{array}$ & $\begin{array}{c}\text { Avg no. of } \\
\text { 5MC per } \\
\text { genome }\end{array}$ \\
\hline $222\left(\mathrm{r}^{-} \mathrm{m}^{-}\right)$ & - & 122,644 & 95 & 0.08 & 2,100 & 156,538 & 203 & 0.13 & 2,450 \\
$222\left(\mathrm{r}^{-} \mathrm{m}_{k}^{-}\right)$ & + & 67,640 & 57 & 0.08 & 2,100 & 48,949 & 696 & 1.42 & 27,000 \\
5GR $\left(\mathrm{r}^{+} \mathrm{m}^{+}\right)$ & - & 178,469 & 23 & 0.01 & $<250$ & 434,791 & 7,455 & 1.69 & 32,000 \\
5GR $\left(\mathrm{r}^{+} \mathrm{m}^{+}\right)$ & + & 24,922 & 49 & 0.20 & 5,100 & 106,651 & 2,020 & 1.90 & 36,000 \\
\hline
\end{tabular}

a The numbers give the sum of two separate chromatographic analyses. The fluctuation between these determinations was less than $10 \%$. The lower limit of detection is $0.01 \%$ methylated base per main base.

TABLE 4. Effects of $M C$ on the in vivo methylation of phage DNA ${ }^{a}$

\begin{tabular}{|c|c|c|c|c|c|c|c|c|c|}
\hline Source of DNA & $\begin{array}{l}\text { Mito- } \\
\text { mycin }\end{array}$ & $A(\mathrm{cpm})$ & $\begin{array}{l}\text { 6MA } \\
\text { (cpm) }\end{array}$ & $\begin{array}{c}\% \text { 6MA/ } \\
\mathbf{A}\end{array}$ & $\begin{array}{l}\text { Avg no. of } \\
6 \mathrm{MA} \text { per } \\
\text { genome }\end{array}$ & $\mathrm{C}$ (cpm) & $\begin{array}{l}\text { 5MC } \\
\text { (cpm) }\end{array}$ & $\% 5 \mathrm{MC} / \mathrm{C}$ & $\begin{array}{l}\text { Avg no. of } \\
5 \mathrm{MC} \text { per } \\
\text { genome }\end{array}$ \\
\hline SPP1.O & - & 82,300 & 32 & 0.04 & 9 & 168,974 & 122 & 0.07 & 11 \\
\hline SPP1 $\cdot M C$ & + & 66,101 & 17 & 0.03 & 7 & 75,735 & 84 & 0.11 & 18 \\
\hline SPO1 & - & 351,789 & 83 & 0.02 & 16 & 336,436 & 70 & 0.02 & 14 \\
\hline SPO1 & + & 85,994 & 42 & 0.05 & 40 & 103,749 & 29 & 0.03 & 20 \\
\hline
\end{tabular}

a Numbers give the sum of two separate chromatographic analyses. The fluctuation between these determinations was less than $10 \%$. The lower limit of detection is $0.01 \%$ methylated base per main base. 
SPP1.MC DNA to complete endoR $B s u \mathrm{R}$ digestion and analyzed the digest by agarose gel electrophoresis (Fig. 4). This analysis reveals the presence of a small portion of SPP1-MC DNA which is completely resistant to enzyme treatment, whereas the remaining material follows essentially the degradation pattern of nonmodified DNA. Although we cannot exclude the possibility that a small fraction of DNA shows intermediary modification, MCinduced modification affects only a minor fraction of molecules, and these are completely modified.

This result is further substantiated by an analysis of the inactivation kinetics of transfecting SPP1 - MC DNA by treatment with the endoR $\cdot B s u \mathrm{R}$ restriction enzyme. A general small increase in the $5 \mathrm{MC}$ content would still not protect all SPP1 molecules from degrada-

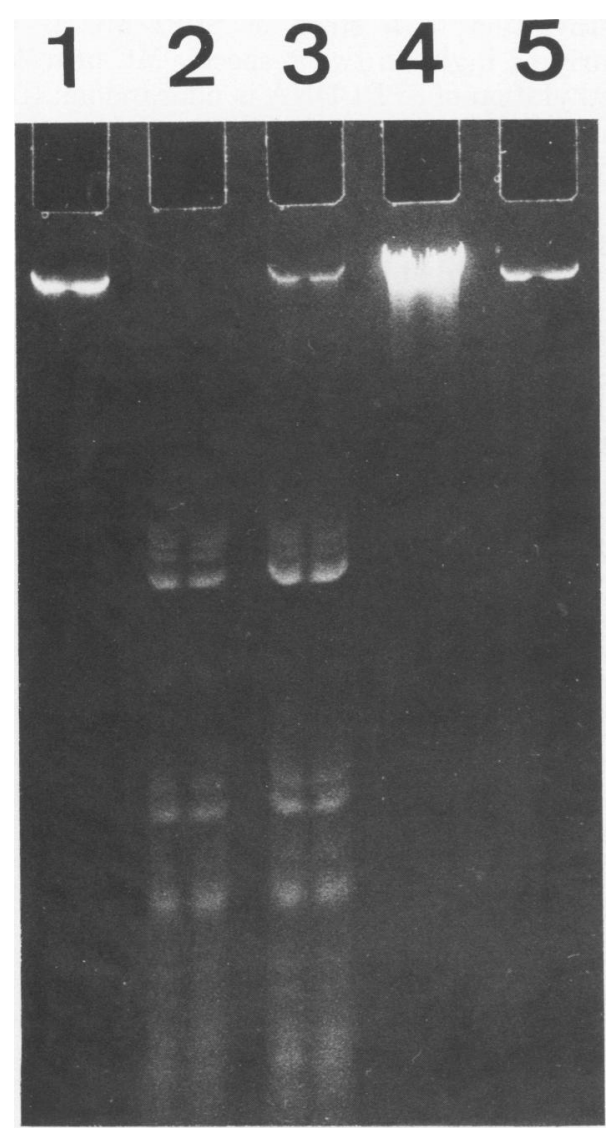

Fig. 4. Agarose gel electropherograms of various SPP1 DNAs after limit digestion with endoR $\cdot B s u R$ restriction enzyme. Tracks contain the following portions: 1, $0.1 \mu \mathrm{g}$ of $S P P 1 \cdot R$ DNA; $2,1 \mu \mathrm{g}$ of $S P P 1 \cdot O$

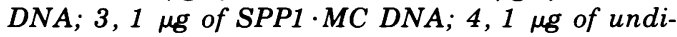
gested SPP1 $\cdot M C D N A ; 5,0.05 \mu \mathrm{g}$ of undigested $S P P 1 \cdot O D N A$. tion by the restriction enzyme. One should, however, expect a reduction in the slope of the inactivation curve indicating decreased sensitivity of the DNA to restriction. On the basis of a highly discontinuous distribution of modification, one would expect a biphasic curve; i.e., the majority of molecules would follow the inactivation curve of SPP1.O DNA, but a minor fraction would be completely resistant. The results shown in Fig. 5 support the latter expectation. The resistant biological activity amounts to $0.1 \%$. Taking into account that SPP1 transfection shows a quadratic dose response (13), this plateau level would be expected if $3 \%$ of the

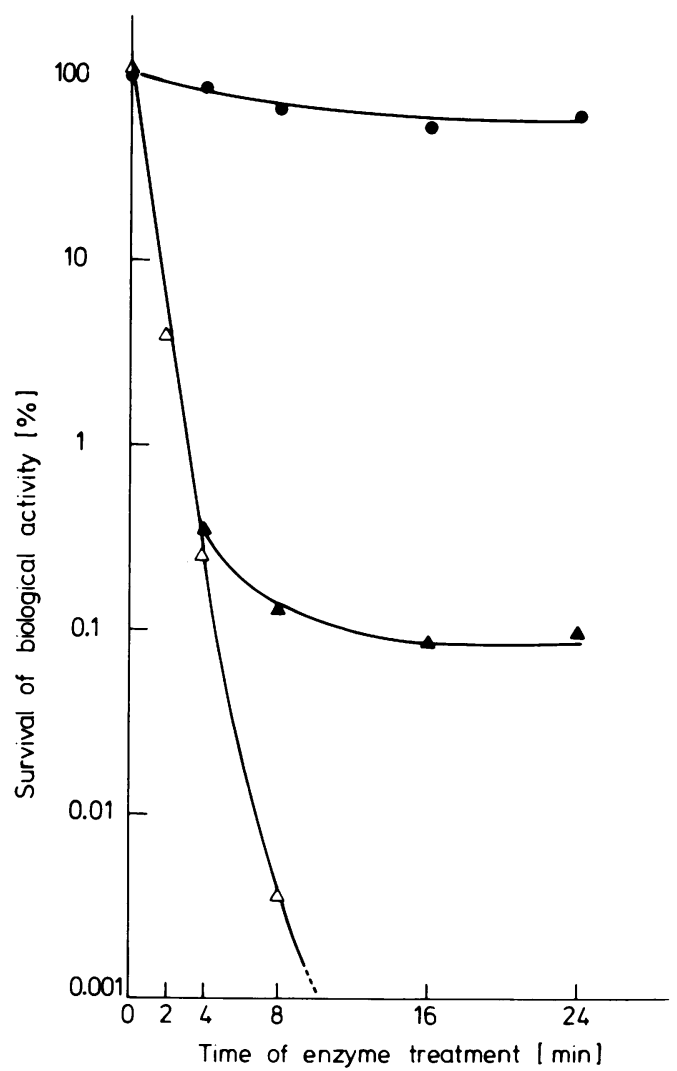

FIG. 5. Inactivation of biological activity of transfecting SPP1 DNA by endoR $\cdot B s u R$ restriction enzyme. SPP1 $O$ DNA ( $\triangle$ ), SPP1 $R$ DNA (O), and $S P P 1 \cdot M C D N A(\Delta)$ were incubated for the times indicated with the DEAE-cellulose enzyme fraction (1/800 dilution) of the endoR $\cdot B s u R$ enzyme. The enzyme reaction was stopped at the indicated times by heating corresponding portions for $10 \mathrm{~min}$ at $68^{\circ} \mathrm{C}$. Such DNA was assayed on competent strain 222 cells by transfection. DNA concentration in the reaction mixtures was $5 \mathrm{\mu g} / \mathrm{ml}$. One hundred percent values of biological activity were (infective centers per milliliter) $2.7 \times 10^{5}(\triangle), 6.7 \times 10^{4}(\bigcirc)$, and $8.0 \times 10^{4}$ ( $\mathbf{\Delta}$. 
SPP1 1 MC molecules carried complete modification.

Levels of methyltransferase activity in crude cell extracts. The methylating activities of crude extracts from $B$. subtilis strains $R$ and 222 (untreated or preincubated with MC) were analyzed with the DNAs of phage SPP1.O, $\mathrm{SPP} 1 \cdot \mathrm{MC}, \mathrm{SPP} 1 \cdot \mathrm{R}$, and SPO1 as substrates (Table 5). As expected, methyltransferase activity is high in extracts of the modifying strain $\mathbf{R}$ in comparison with extracts of the nonmodifying strain 222 . However, MC treatment of 222 cells enhances the level of methyltransferase at least 30 -fold. The final methyltransferase level obtained in the total extract is about $10 \%$ of that found in $\mathbf{R}$ strains. This activity suffices to produce the degrees of methylation observed in DNAs from MC-pretreated cells. Extracts from MC-treated 222 and untreated $\mathrm{R}$ cells show very similar substrate specificities: with both extracts, the highest incorporation of methyl groups is into SPP1.O DNA, slightly less is incorporated into SPP1 $\cdot \mathrm{MC}$ DNA, and very little is incorporated into the SPP1.R and SPO1 DNAs. The difference in the capacity of SPP1. O and SPP1 - MC DNAs to accept methyl groups is compatible with our other results (Fig. 4 and 5), indicating that only a small fraction of the SPP1 $\cdot \mathrm{MC}$ molecules carry Rspecific modification. The low capacity of SPO1 DNA to be methylated by crude extracts is in agreement with DNA analyses of methylated bases, which showed that this DNA is not a substrate for $R$-specific modification in vivo either (6). The estimated amount of incorporated methyl groups into an SPP1. O DNA molecule by the $R$ strain extracts is somewhat more (235) than the number observed in the naturally modified SPP1 $R$ molecule, which is 190 (6). We attribute this, and also the fact that slight methylation of SPP1 R DNA still occurs by the "homologous" $R$ enzyme, to the use of in vitro conditions.

\section{DISCUSSION}

MC treatment, and possibly also UV irradiation, induce in nonmodifying $B$. subtilis cells the formation of a DNA methyltransferase activity. The specificities of the MC-provoked methyltransferase and the modification enzyme found in extracts of restricting/modifying cells are very similar. The important question of whether these two activities are due to identical enzymes must await their purification. Such studies are presently being undertaken.

Methylation of $\mathrm{C}$ to $5 \mathrm{MC}$ in bacterial DNA after MC treatment approaches the level observed in DNA from modifying type $\mathrm{R}$ strains. Methylation in a stock of SPP1.MC is not nearly as high. In two respects, MC-provoked methylation of SPP1 DNA is nonrandom: (i) at least some modified phages originate from larger bursts of a few MC-treated cells (Table 2). We cannot determine whether cells releasing modified phages in addition produce sensitive phage; (ii) at least the majority of modified phages are completely modified; i.e., there is no indication of the presence of DNA molecules with intermediate modification (Fig. 4 and 5).

The restriction ratio of $2.4 \times 10^{-2}$ in SPP1.MC stocks (Table 1) can readily be accounted for by the presence in the population of 2 to $3 \%$ completely modified phages. This value is in good agreement with (i) the level of residual transfecting activity of SPP1 - MC DNA exposed to degradation with the endoR $B s u \cdot R$

TABLE 5. DNA methyltransferase activities in crude cell extracts.

\begin{tabular}{|c|c|c|c|c|}
\hline Origin of crude extract & DNA substrates & $\begin{array}{l}\text { Methyl groups } \\
\text { incorporated } \\
(\text { pmol })\end{array}$ & $\begin{array}{c}\text { Relative methyla- } \\
\text { tion levels } \\
(\mathrm{SPP} 1 \cdot \mathrm{O} \text { DNA }= \\
100 \%)\end{array}$ & $\begin{array}{l}\text { Methyl groups } \\
\text { incorporated } \\
\text { per DNA mol- } \\
\text { ecule }^{a}\end{array}$ \\
\hline \multirow[t]{4}{*}{ Bsu $\mathbf{R}\left(\mathbf{r}^{+} \mathrm{m}^{+}\right)$} & $\mathrm{SPP} 1 \cdot \mathrm{O}$ & 73.0 & 100 & 235 \\
\hline & $\mathrm{SPP} 1 \cdot \mathrm{MC}$ & 68.3 & 94 & 220 \\
\hline & SPP1·R & 3.9 & 5 & 12 \\
\hline & SPO1 & 1.3 & 2 & 16 \\
\hline \multirow[t]{4}{*}{ Bsu $222\left(\mathrm{r}^{-} \mathrm{m}^{-}\right)-\mathrm{MC}$} & SPP1 $\cdot 0$ & 0.1 & 0 & $<1$ \\
\hline & $\mathrm{SPP} 1 \cdot \mathrm{MC}$ & 0.1 & 0 & $<1$ \\
\hline & SPP1·R & $<0.1$ & 0 & 0 \\
\hline & SPO1 & $<0.1$ & 0 & 0 \\
\hline \multirow[t]{4}{*}{ Bsu $222\left(\mathrm{r}^{-} \mathrm{m}^{-}\right)+\mathrm{MC}$} & $\mathrm{SPP} 1 \cdot \mathrm{O}$ & 6.4 & 100 & 20 \\
\hline & $\mathrm{SPP} 1 \cdot \mathrm{MC}$ & 4.7 & 75 & 15 \\
\hline & $\mathrm{SPP} 1 \cdot \mathbf{R}$ & 0.7 & 10 & 2 \\
\hline & SPO1 & $<0.1$ & 0 & 0 \\
\hline
\end{tabular}

$a$ The measured specific activity of $S$-adenosyl-L-[methyl $\left.-{ }^{3} \mathrm{H}\right]-$ methionine is $3,250 \mathrm{cpm} / \mathrm{pmol}$. 
restriction enzyme (Fig. 5), (ii) the degradation pattern of SPP1 - MC DNA observed after limit digestion with endoR $\cdot B s u R$ (Fig. 4), (iii) the extent of DNA methylation (Table 4), and is (iv) compatible with the degree to which SPP1.MC DNA can be further methylated by crude cell extracts (Table 5).

The MC inducibility of a modification-type methyltransferase activity in phenotypically nonmodifying cells implies that the genetic information for such an enzyme(s) must be present in these cells. We are presently investigating whether such a genetic determinant(s) is identical to those mapped in type $R$ cells (15). The question arises, why is such information expressed after treatment with agents known to cause prophage induction? It is conceivable, as pointed out by Arwert and Rutberg (1), that genes for modification (and possibly restriction) enzymes are carried by an unexpressed defective inducible prophage in $\mathrm{r}^{-} \mathrm{m}^{-}$cells which become manifest after induction. The induction of methyltransferases after phage T2 infection or induction of $\lambda$ has been reported by Wainfan et al. (16). In our system the induction of modifying activity and the presence of defective prophage PBSX (11) were correlated by Arwert and Rutberg (1). However, subsequently A. Garro (personal communication) observed that modifying activity could also be induced in cells with noninducible PBSX prophage. Although this finding makes the connection between induction of PBSX and methyltransferase somewhat more complicated, it does not affect the generality of the concept of a correlation between enzyme and prophage induction, especially in view of the existence of many other defective prophages in $B$. subtilis (5).

\section{ACKNOWLEDGMENTS}

We thank W. Arber and our colleagues in Berlin, particularly M. Achtman, for their criticism of the manuscript, B. Behrens for performing the agarose electrophoresis experiment, and $\mathbf{R}$. Thompson for acquainting us with this technique.

\section{LITERATURE CITED}

1. Arwert, F., and L. Rutberg. 1974. Restriction and modification in $B$. subtilis. Induction of a modifying activity in Bacillus subtilis 168. Mol. Gen. Genet. 133:175177.

2. Bron, S., and K. Murray. 1975. Restriction and modification in $B$. subtilis. Nucleotide sequence recognized by restriction endonuclease $R \cdot B s u$ from strain $R$. Mol. Gen. Genet. 143:25-33.

3. Bron, S., K. Murray, and T. A. Trautner. 1975. Restriction and modification in B. subtilis. Purification and general properties of a restriction endonuclease from strain R. Mol. Gen. Genet. 143:13-23.

4. Esche, H., M. Schweiger, and T. A. Trautner. 1975. Gene expression of bacteriophage SPP1. I. Phage directed protein synthesis. Mol. Gen. Genet. 142:45-55.

5. Garro, A. J., and J. Marmur. 1970. Defective bacteriophages. J. Cell. Physiol. 76:253-264.

6. Günthert, U., J. Stutz, and G. Klotz. 1975. Restriction and modification in B. subtilis. The biochemical basis of modification against endo R.Bsu R. Mol. Gen. Genet. 142:185-191.

7. Lowry, O. H., N. J. Rosebrough, A. L. Farr, and R. J. Randall. 1951. Protein measurement with the Folin phenol reagent. J. Biol. Chem. 193:265-275.

8. Okubo, S., B. Strauss, and M. Stodolsky. 1964. The possible role of recombination in the infection of competent $B$. subtilis by bacteriophage DNA. Virology 24:552-562.

9. Riva, S., M. Polsinelli, and A. Falaschi. 1968. A new phage of $B$. subtilis with infectious DNA having separable strands. J. Mol. Biol. 35:347-356.

10. Rottländer, E., and T. A. Trautner. 1970. Genetic and transfection studies with $B$. subtilis phage SP50. I. Phage mutants with restricted growth on $B$. subtilis strain 168. Mol. Gen. Genet. 108:47-60.

11. Seaman, E., E. Tarmy, and J. Marmur. 1964. Inducible phages of Bacillus subtilis. Biochemistry 3:607-613.

12. Spatz, H. Ch., and T. A. Trautner. 1970. One way to do experiments on gene conversion? Mol. Gen. Genet. 109:84-106

13. Spatz, H. Ch., and T. A. Trautner. 1971. The role of recombination in transfection of $B$. subtilis. Mol. Gen. Genet. 113:174-190.

14. Spizizen, J. 1958. Transformation of biochemically deficient strains of Bacillus subtilis by deoxyribonucleate. Proc. Natl. Acad. Sci. U.S.A. 44:1072-1078.

15. Trautner, T. A., B. Pawlek, S. Bron, and C. Anagnostopoulos. 1974. Restriction and modification in $B$. subtilis. Biological aspects. Mol. Gen. Genet. 131:181-191.

16. Wainfan, E., P. R. Srinivasan, and E. Borek. 1965 Alterations in the transfer ribonucleic acid methylases after bacteriophage infection or induction. Biochemistry 4:2845-2848. 